Research Report

\title{
An Overview of Risk Factors Influencing Severity Levels of Dental Caries in Public Islamic Elementary School Students in an Endemic Leprosy-Populated Village in East Java
}

\author{
Aulia Ramadhani' ${ }^{1}$, M. Khafid ${ }^{2}$, Dicky Daruanggono ${ }^{2}$, Chusnul Chotimah ${ }^{2}$, M. Taufik Arisetiawan ${ }^{2}$, Nur Indah \\ Metikasari $^{2}$, Revinska Bagus Irawan ${ }^{2}$, Annisa Galuh RHP ${ }^{3}$, Nastiti Sarilaksmi², Rizki Widyakartika Y², Dinar \\ Arijati $^{2}$, Haninda Iffatuz ${ }^{4}$ \\ ${ }^{1}$ Department of Dental Public Health, Faculty of Dental Medicine, Universitas Airlangga, Surabaya, Indonesia \\ ${ }^{2}$ Profession Program Student, Faculty of Dental Medicine, Universitas Airlangga, Surabaya, Indonesia \\ ${ }^{3}$ Resident of Pediatric Dentistry Department, Faculty of Dentistry, Universitas Indonesia, Jakarta, Indonesia \\ ${ }^{4}$ Graduate Student of Dental Health Science, Faculty of Dental Medicine, Universitas Airlangga, Surabaya, Indonesia
}

\begin{abstract}
Background: Dental caries is the destruction of hard tissues of the teeth due to activities of bacteria that change food debris, especially sugar and starch into acid and then demineralize the teeth. Dental caries is a common infection affecting mostly schoolchildren as they usually consume snacks at schools and rarely have mineral water after. Based on the research, $28.5 \%$ of children in the age of 5-9 years and $25.2 \%$ of children in the age of $10-14$ years have oral health problems. Purpose: This study assessed the risk factors influencing the severity levels of dental caries. Methods: This study was observational descriptive research using a cross-sectional approach. The samples used in this study were 118 students selected through stratified proportional random sampling. Data were collected through interviews, intra-oral examination, and school data observation. All data collected were analyzed using cross-tabulation and odds ratio with the SPSS program. Results: As many as $68.6 \%$ of the respondents had highly severe dental caries (dmf-t $>3$ ). The value of the odds ratio between the severity of caries and oral hygiene status was 5.63. While the value of the odds ratio between the severity of caries and water drinking after snacking was 1.89 . The odds ratio tests showed oral hygiene status and water drinking after snacking were the risk factors of caries. Conclusion: Age, gender, parent's knowledge, parent's occupation, snacking habit, teeth-brushing habit, water drinking habit, and oral hygiene status were the risk factors influencing the severity levels of dental caries.
\end{abstract}

Keywords: dental caries; DMF index; oral hygiene; children

Correspondence: Aulia Ramadhani, Department of Public Dental Health. Faculty of Dental Medicine Universitas Airlangga. Jl. Mayjend Prof. Dr. Moestopo 47 Surabaya, 60123, Indonesia. Email: ramadhani.rara94@gmail.com

\section{INTRODUCTION}

Caries is an infection commonly found in humans. Caries is a destruction of the hard tissues in the teeth due to bacteria fermenting food lodged on the teeth, thereby producing acid and dissolve minerals on the teeth. Caries occurs because of the continuous demineralization process without balancing the remineralization process. The substrate component which often causes caries is a carbohydrate that can be fermented by bacteria. One type of specific carbohydrate which often causes caries is sucrose. ${ }^{1,2}$

Elementary school children generally have high risks of caries as they like consuming snacks of their interest. Children at schools rarely drink water after snacking, and thus food gets lodged on the teeth and turns out to increase the risk of caries.

The Basic Health Research in 2013 showed the rate of dental and oral health problems in elementary school children aged 5-9 years was at $28.9 \%$, and only $35.1 \%$ of the children with caries received treatment. Meanwhile, in children aged 10-14 years, the rate was at $25.2 \%$, and $28.3 \%$ of the children with caries were treated. It shows a lack of public awareness of taking dental check-up in health service providers.

The Bendunganjati village is one of the villages in the Pacet sub-district, Mojokerto district. It is one of the villages in Mojokerto that is leprosy-endemic and has 7 sub-villages. The Bendunganjati Public Islamic Elementary School was 
chosen as a research location since it has a representative number of students that can give an overview of caries in children in the village. A high rate of caries in children aged 5-9 years in Indonesia is the basis for conducting this current study to identify the severity levels of caries in Bendunganjati Public Islamic Elementary School.

\section{MATERIALS AND METHODS}

The research was observational descriptive and used a crosssectional design. The samples were taken from students in grades 1-6 of Bendunganjati Public Islamic Elementary School. The number of samples was selected through stratified proportional random sampling.

Data collection was conducted through 3 methods which were interviews, school data observation, and intraoral examination. Interviews were conducted using an interview guide to gather the information about respondents' identities, tooth-brushing habit, snacking habit, visits to dental and oral health service providers, and water drinking habit after eating. The observation of the school's data aimed to collect the respondents' identities, parents' education level, and parents' employment.

While, an intraoral examination was done to identify the severity levels of caries, dental structure, and oral hygiene status. The severity levels of caries were measured using def-t and DMF-t methods. During the examination, if decays were assessed using a half-moon nasogastric tube lodged in the cavity. Teeth would be considered exfoliative or missing if the teeth were not able to retain and erupted before the date. In addition to those two conditions, teeth would be considered filling if there were teeth filled. Dental structures were determined from the presence and absence of anterior teeth outside the normal cavity. The oral hygiene status was determined from the index of Personal Hygiene Performance (PHP).

The collected data were then analyzed using crosstabulation, and the odds ratio between caries and other factors was analyzed using SPSS 22 (IBM, New York).

\section{RESULTS}

The results showed an overview of the severity levels of caries in 118 students of Bendunganjati Public Islamic Elementary School. The characteristics of the samples included sexes, age, parent's employment, and parents' education level (see Table 1).

The severity levels of caries were categorized as low and high. It would be considered high caries if a def-t and/or DMF-T degree was above the mean. Conversely, if a def-t and/or DMF-T was below the mean, it would be considered low caries severity. Overall, the distribution of caries severity levels is presented in Figure 1. As many as 81 respondents had highly severe caries.

Data obtained from the questionnaire were crosstabulated with the caries severity levels. The variables in the questionnaire were age, sexes, parents' education level, parents' employment, frequency of snacking, snacking habit, water drinking habit, tooth-brushing habit, oral hygiene status, time for tooth-brushing, dental structures, and access to healthcare centers.

The odds ratio of the two risk factors was significant (value $>1$ ). It indicated that the two factors contributed to the caries severity levels. Table 2 displays all variables as risk factors of caries severity excluding tooth-brushing routine and the availability of access to healthcare providers.

Table 1. Respondents' Characteristics

\begin{tabular}{|c|c|c|c|}
\hline Variables & Mean \pm SD & Range & $\%$ \\
\hline Age & & $6-12$ & \\
\hline 6-8 years & & & 48.3 \\
\hline $9-12$ years & & & 51.7 \\
\hline \multicolumn{4}{|l|}{ Sexes } \\
\hline Male & & & 49.2 \\
\hline Female & & & 50.8 \\
\hline \multicolumn{4}{|l|}{ Parents' employment } \\
\hline Formal & & & 34.7 \\
\hline Non-formal & & & 65.3 \\
\hline \multicolumn{4}{|l|}{ Parents' education } \\
\hline $\begin{array}{l}\text { Elementary School - } \\
\text { Junior High School }\end{array}$ & & & 71.2 \\
\hline $\begin{array}{l}\text { Senior High School - } \\
\text { Higher Education }\end{array}$ & & & 28.8 \\
\hline def-t & $5.85 \pm 4.3$ & & \\
\hline$>$ mean & & & 51.7 \\
\hline$<$ mean & & & 48.3 \\
\hline DMF-T & $1.24 \pm 1.8$ & & \\
\hline$>$ mean & & & 66.1 \\
\hline$<$ mean & & & 33.9 \\
\hline Oral hygiene status & $1.73 \pm 0.85$ & & \\
\hline Good & & & 55.1 \\
\hline Poor & & & 44.9 \\
\hline
\end{tabular}

Caries Severity Levels

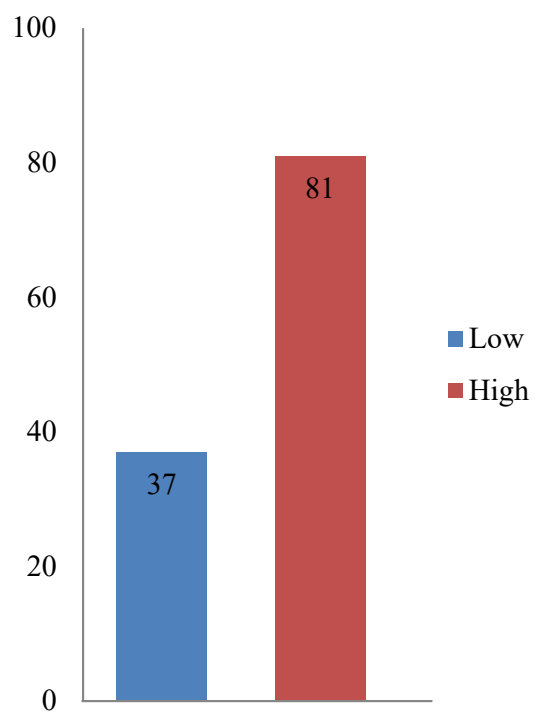

Figure 1. Graph of Caries Severity Levels. 
Indonesian Journal of Dental Medicine Volume 3 Issue 2 2020; 37-40

Table 2. Distribution of Caries Severity Levels based on Causing Risk Factors

\begin{tabular}{|c|c|c|c|c|c|c|}
\hline & & \multicolumn{2}{|c|}{ Caries Severity } & \multicolumn{2}{|c|}{$\begin{array}{l}95 \% \text { Confidence Interval for } \\
\text { Odds ratio }\end{array}$} & \multirow{2}{*}{ Odds Ratio } \\
\hline & & High & Low & Lower & Upper & \\
\hline \multirow{2}{*}{ Age } & $6-8$ years & $44(77.2 \%)$ & $13(22.8 \%)$ & \multirow{2}{*}{0.982} & \multirow{2}{*}{4.906} & \multirow{2}{*}{$2.195^{*}$} \\
\hline & $9-12$ years & $37(60.7 \%)$ & $24(39.3 \%)$ & & & \\
\hline \multirow{2}{*}{ Sexes } & Male & $41(70.7 \%)$ & $17(29.3 \%)$ & \multirow{2}{*}{0.553} & \multirow{2}{*}{2.630} & \multirow{2}{*}{$1.206^{*}$} \\
\hline & Female & $40(66.7 \%)$ & $20(33.3 \%)$ & & & \\
\hline \multirow{2}{*}{ Parents' education levels } & $\begin{array}{l}\text { Elementary School- } \\
\text { Junior High School }\end{array}$ & $59(70.2 \%)$ & $25(29.8 \%)$ & \multirow{2}{*}{0.553} & \multirow{2}{*}{2.996} & \multirow{2}{*}{$1.287 *$} \\
\hline & $\begin{array}{l}\text { Senior High School- } \\
\text { Higher Education }\end{array}$ & $22(64.7 \%)$ & $12(35.3 \%)$ & & & \\
\hline \multirow{2}{*}{ Parents' employment } & Non-formal & $54(69.2 \%)$ & $24(30.85 \%)$ & \multirow{2}{*}{0.478} & \multirow{2}{*}{2.455} & \multirow{2}{*}{$1.083^{*}$} \\
\hline & Formal & $27(67.5 \%)$ & $13(32.5 \%)$ & & & \\
\hline \multirow{2}{*}{ Snacking habit } & Solid food & $71(68.9 \%)$ & $32(31.1 \%)$ & \multirow{2}{*}{0.351} & \multirow{2}{*}{3.510} & \multirow{2}{*}{$1.109 *$} \\
\hline & Liquid food & $10(66.7 \%)$ & $5(33.3 \%)$ & & & \\
\hline \multirow{2}{*}{ Frequency of snacking } & Seldom & $26(72.2 \%)$ & $10(27.8 \%)$ & \multirow{2}{*}{0.539} & \multirow{2}{*}{3.024} & \multirow{2}{*}{$1.276^{*}$} \\
\hline & Often & $55(67.1 \%)$ & $27(32.9 \%)$ & & & \\
\hline \multirow{2}{*}{ Water drinking habit } & No & $50(74,6 \%)$ & $17(25,4 \%)$ & \multirow{2}{*}{0.864} & \multirow{2}{*}{4.167} & \multirow{2}{*}{$1.898^{*}$} \\
\hline & Yes & $31(60,8 \%)$ & $20(39,2 \%)$ & & & \\
\hline \multirow{2}{*}{$\begin{array}{l}\text { Toothbrushing frequency } \\
\text { a day }\end{array}$} & Seldom & $15(75 \%)$ & $5(25 \%)$ & 0486 & 4355 & $1455^{*}$ \\
\hline & Often & $66(67.3 \%)$ & $32(32.7 \%)$ & 0.486 & 4.355 & $1.455^{*}$ \\
\hline & Poor & $46(86,8 \%)$ & $7(13,2 \%)$ & & & \\
\hline Oral hygiene status & Good & $35(68,8 \%)$ & $30(46,2 \%)$ & 2.216 & 14.316 & $5.633^{*}$ \\
\hline Time for tooth-brushing & Incorrect & $23(76.7 \%)$ & $7(23.3 \%)$ & 0655 & 4412 & $1700 *$ \\
\hline lime ror tooth-brusning & Correct & $58(65.9 \%)$ & $30(34.1 \%)$ & 0.655 & 4.412 & $1.700^{*}$ \\
\hline Tooth-brushing routine & Not routine & $47(63.5 \%)$ & $27(36.5 \%)$ & 0210 & 1197 & 0.512 \\
\hline & Routine & $34(77.3 \%)$ & $10(22.7 \%)$ & 0.219 & 1.191 & 0.512 \\
\hline Dental Structure & Crowded & $31(72,1 \%)$ & $12(27,9 \%)$ & 0568 & 2937 & $1292 *$ \\
\hline Dental Structure & Normal & $50(66,7 \%)$ & $25(33,3 \%)$ & 0.568 & 2.931 & $1.292^{\circ}$ \\
\hline Access to Healthcare & No & $57(67.9 \%)$ & $27(32.1 \%)$ & 0360 & & \\
\hline Centers & Yes & $24(70.6 \%)$ & $10(29.4 \%)$ & 0.369 & 2.096 & 0.880 \\
\hline
\end{tabular}

*odds ratio (value $>1$ )

\section{DISCUSSION}

Caries is infectious diseases caused by enamel and dentine demineralization which is closely related to cariogenic food. Streptococcus mutans has a significant role in the dental demineralization process. ${ }^{3}$

The study showed 81 students or about $68.6 \%$ of the total samples had highly severe caries. Of the students having highly severe caries, 46 students had a poor oral hygiene status. Oral hygiene status indicated to what extent they took care of their oral hygiene, but this fluctuated as influenced by other factors, such as tooth-brushing, water drinking, and dental structure.

One of the factors causing caries is an accumulation of plaque and debris on the dental surface. In school children, the accumulation of plaque can be reduced by routine water drinking after eating or snacking. ${ }^{4,5}$ The results show students who had no water drinking habit after snacking or eating had more severe caries than those who had the habit. Water can dissolve glucose in meals or snacks that the student consumed, and thus it has a capacity of rinsing. ${ }^{6-8}$

The results also revealed children with a crowded dental structure had more severe caries than those having a normal dental structure. Besides, children with a crowded dental structure had poorer oral hygiene than those with a normal dental structure. Crowded teeth are hardly cleaned naturally during mastication. It is rather difficult to clean teeth and oral cavity with a toothbrush or dental floss if teeth are crowded or overlapped. Therefore, this condition could cause dental caries. ${ }^{9}$

In this study, it was obtained that the number of children who accessed dental healthcare services mostly had good oral hygiene compared to bad oral hygiene. It corroborates with a theory that says access to dental and oral healthcare services influences the level of caries severity. Children who take dental care or treatment in healthcare providers can get a service and preventive education from severe caries. Visits to dental healthcare center aim to receive an examination of caries risk, initiative, and preventive treatment, and parental guide as anticipation to reduce the prevalence of caries in children.

However, the number of children who never or rarely accessed healthcare services and had good oral hygiene was greater than those with poor oral hygiene. Healthcare services are only accessed to get treatment for having dental and oral problems; as a result, children with good oral hygiene tend to not access oral and dental healthcare centers such as primary healthcare centers or nearby dentists. In Indonesia, visits to dentists have not been routinely done, especially among children. Visits are undertaken when there is a complaint and a preventive program has not been implemented well. The perception that baby teeth are temporarily located in the oral cavity makes most of the parents not aware of its treatment. ${ }^{10}$ 
Indonesian Journal of Dental Medicine Volume 3 Issue 2 2020; 37-40

\section{REFERENCES}

1. Balakrishnan M, Simmonds RS, Tagg JR. Dental caries is a preventable infectious disease. Aust Dent J. 2000 Dec;45 (4):235-45.

2. Featherstone JDB. Dental caries: a dynamic disease process. Aust Dent J. 2008 Sep;53(3):286-91.

3. Ami A. Pencegahan Primer Pada Anak Yang Berisiko Karies Tinggi. Medan: Skripsi Fakultas Kedokteran Gigi Departemen Pedodonsia Universitas Sumatera Utara;2005.

4. Brown JP, Dodds MWJ. Dental caries and Assosiated Risk Factor and Clinical Oral Health Care. Missuori : Mosby Elsevier, 2008.

5. Touger-Decker R, van Loveren C. Sugars and dentalcaries. Am J Clin Nutr. 2003 Oct; 78(4):
881S-892S.

6. Beth O, Cristine T. Nutrition and Oral Health for Children. Nutr Focus. 2003;18(6).

7. American Dental Association. Amerika: Fluoridation Facts ; 2005.

8. Dumasari, B. Hubungan kebiasaan makan dan pemeliharaan kesehatan gigi dengan karies gigi pada anak SD di jalan Pintu Air II Simpang Gudang Kota Medan tahun 2008. Medan: Skripsi USU; 2010.

9. Donald MC, Ralph E. Dental caries in the child and adolsecent. Dentistry for the Child and Adolscent. Mosby: Elsevier; 2005. chapter 10, 20 p.

10. Pertiwi ASP. Korelasi status kesehatan mulut antara ibu dan anak di SD Sukapura, Kecamatan Sukaraja, Kabupaten Tasikmalaya. Maj Ilmu Kedokt Gigi. 2009;XI(1). 